\title{
APOBEC3A wt Allele
}

National Cancer Institute

\section{Source}

National Cancer Institute. APOBEC3A wt Allele. NCI Thesaurus. Code C116999.

Human APOBEC3A wild-type allele is located within 22q13.1-q13.2 and is approximately $10 \mathrm{~kb}$ in length. This allele, which encodes DNA dC->dU-editing enzyme APOBEC-3A protein, plays a role in the modulation of viral DNA modification. A deletion that fuses this gene and the $3^{\prime}$ end of the APOBEC3B gene may be associated with increased susceptibility to neoplastic disease. 